\title{
Yeni Doğum Yapmış Annelerin Anne Sütü ile İlgili Uygulama ve Görüşleri: Aydın’da Bebek Dostu Hastane Örneği
}

\author{
Meryem Tüğdür ${ }^{1} \oplus$, Serdal Öğüt ${ }^{2} \oplus$, Ayşe Demet Karaman ${ }^{3} \oplus$, Nurhan Günay ${ }^{4} \oplus$
}

'Aydın Kadın Doğum ve Çocuk Hastalıkları Hastanesi, Aydın, Türkiye ${ }^{2}$ Aydın Adnan Menderes Üniversitesi, Sağlık Bilimleri Fakültesi, Beslenme ve Diyetetik Bölümü, Aydın, Türkiye ${ }^{3}$ Aydın Adnan Menderes Üniversitesi, Ziraat Fakültesi, Süt Teknolojisi Bölümü, Aydın, Türkiye ${ }^{4}$ Aydın Adnan Menderes Üniversitesi, Köşk MY0, Gıda İşleme Bölümü, Aydın, Türkiye

Meryem Tüğdür, Hemşire

Ayşe Demet Karaman, Doç.Dr.

Serdal Öğüt, Doç.Dr.

Nurhan Günay, Öğr. Gör.

İletişim:

Doç. Dr. Ayșe Demet Karaman

Aydın Adnan Menderes Üniversitesi, Ziraat Fakültesi, Süt Teknolojisi Bölümü, Aydın, Türkiye Tel: +902567727022

E-Posta: demet.karaman@adu.edu.tr

Gönderilme Tarihi : 31 Aralık 2018

Revizyon Tarihi : 07 Haziran 2019

Kabul Tarihi : : 29 Ağustos 2019
ÖZET

Amaç: Anne sütü özellikle 0-2 yaş grubunun beslenmesinde gerekli ideal bir besindir. Bebeklerin ilk altı ay sadece anne sütü tüketmesi önerilmektedir. Bu araștırma ile annelerin anne sütü ile ilgili uygulama ve görüşleri ve emzirme ile ilgili faktörlerin belirlenmesi ve annelere bilgi verilerek önerilerde bulunulması amaçlanmıştır.

Yöntem: Araştırmada, Aydın Kadın Doğum ve Çocuk Hastanesi'nde yeni doğum yapmış 280 anneye anne sütü ile emzirme uygulama ve görǚşleri ile ilgili anket uygulaması yapıımıştı.

Bulgular: Ankete katılan annelerin çoğunluğu ilkokul veya ortaokul mezunu $(\% 72,5)$, ev hanımı olan $(\% 80,7)$ normal doğum yapan $(\% 61,4)$ annelerden oluşmaktadır. Anket sonuçları değerlendirildiğinde, annelerin hemen hemen tamamının $(\% 98,9)$ bebeklerini doğumdan hemen sonra anne sütü ile beslediği, doğumda ve doğumdan sonra sağlık personelinden anne sütü ve emzirme konusunda çeşitli eğitimler aldıkları tespit edilmiştir. Yapılan istatistiksel analizler sonucunda ise annenin bebeğini emzirme süresinin arttırılmasında, annenin gebelikte ve doğumdan sonra aldığı eğitimlerin ve emzirme süresince eşten alınacak çeşitli desteklerin en önemli etkenlerden olduğu saptanmıştır $(p<0,05)$.

Sonuç: Annelerin bebeklerini emzirme sürelerinin artmasında, bebek dostu hastaneler başta olmak üzere tüm sağlık kurumlarında babalara yönelik uygulamaların desteklenmesi, annelere verilen eğitimlerin ev ziyaretleri yoluyla izlenmesi kanısına varılmıştır.

Anahtar sözcükler: Anne sütü, besleme süresi, faktörler, bebek dostu hastane

THE PRACTICE AND VIEW OF BREASTFEEDING AMONG MOTHERS: A QUESTIONNAIRE-BASED SURVEY IN BABY FRIENDLY HOSPITAL IN AYDIN

\section{ABSTRACT}

Objective: Breast milk is the ideal food that is particularly essential for 0-2 aged babies. It is recommended to consume breast milk specifically in the first six months of life. This study aims to find out the mothers' practices and opinions about breast milk and the factors related to breastfeeding and to give information to the mothers and make recommendations.

Materials and Methods: In this research, a survey about the breastfeeding practices and points of view is applied to 280 mothers who had given birth in Aydın Maternity and Children Hospital were questioned about breastfeeding and their knowledge and opinions about it

Results: The majority of the mothers who have taken the survey were graduated primary and middle school ( $72.5 \%)$, housewives $(80.7 \%)$, mothers who had a natural childbirth $(61.4 \%)$. When the results of the survey are evaluated, it is identified that nearly all the mothers $(98.9 \%)$ have breastfed their babies just after the birth and taken different training from medical staff while and after pregnancy about lactation and breastfeeding. As a result of the statistical analysis, it is identified that the most important factors in increasing the duration of breastfeeding are the training taken by the mother while and after pregnancy about lactation and breastfeeding and some kind of support given by the husband during breastfeeding $(p<0.05)$.

Conclusion: In our study, we concluded that the support given by the husbands in all health institutions, especially in babyfriendly hospitals and supporting training and education given to the mothers with home visits are necessary to increase the duration of breastfeeding. .

Keywords: Lactation, breastfeeding duration, factors, baby-friendly hospital 
E mzirme insan türünün hayatta kalmasının ve annelik sembolünün anahtarıdır. Doğumdan sonra ilk 6 ay boyunca bebeğin fizyolojik ve psikososyal ihtiyaçlarını tek başına karşılamaya yeten anne sütü, anne ve bebek bağının kurulmasında da önemli rol oynar (1). Yaşamın erken aylarında tek başına anne sütüyle beslenme infant sağ kalımında artış ve ishalli hastalıklar başta olmak üzere hastalık riskinde azalma ile yakından ilişkilidir (2). Emzirmenin yıllık olarak 5-6 milyon çocuğu sık görülen enfeksiyon hastalıklarından koruduğu tahmin edilmektedir. Lancet Çocuk Sağkalım serilerine göre eğer anne ilk 6 ay sadece anne sütüyle besler ve sonrasında ek gıdalarla birlikte emzirmeye devam ederse ek olarak 1,3 milyon yaşamın daha korunacağı tahmin edilmektedir (3). Yapılan çalışmalar, anne sütünün, yeni doğanın immün gelişimi ile büyüme ve gelişmesi için gerekli tüm proteinleri, lipidleri, karbonhidratları, mikrobesin öğelerini ve eser elementleri optimal düzeyde içerdiğini göstermiştir. Bu nedenle anne sütü, çocukluk çağı kanserlerinin, obesite ve gastrointestinal hastalıkların önlenmesinde önemli rol oynamaktadır (4).

Çeşitli nedenlerle anne sütü alamayan bebeklerle birlikte ilk 6 ayda beslenme 4 grupta toplanır. Zamanında ya da erken doğan tüm bebeklerin yaşamlarının ilk 6 ayında sadece anne sütü ile beslenmesi önerilir. 6. aydan sonra ek gıdalarında beslenmeye eklemesi ile karışık beslenmeye geçilir (5). Ancak yapılan çalışmalarda ülkemizde anne sütü ile beslenme oranının ikinci aydan itibaren düştüğü, tek başına 6 ay anne sütü verme oranının da düşük olduğu tespit edilmiştir. Bu nedenle özellikle gebe ve yeni doğum yapan annelerin daha fazla eğitim ve desteğe ihtiyacı olduğu aşikârdır (6).

Türkiye'de annelerin \%95'i bebeğini emzirmektedir. Üstelik eğitim düzeyi, yaşı, yaşadığı bölge ne olursa olsun bu oran çok değişmemektedir. Ancak bebeği emzirmeye geç başlamak, ilk emzirmeden önce şekerli su gibi besinler vermek, ek besinler vermek, ek besinlere erken ya da geç başlamak gibi hatalı uygulamalar, yeterli ve kaliteli bir emzirme programını engellemektedir (7).

Emzirme, yalnızca bir bebek beslenme uygulaması değildir. Yetişkin eğitimi açısından anne ve çocuk sağlığını koruyucu bir uygulamadır. Bebeklerin anne sütü ile beslenmesi gelecek nesillerin sağlıklı olmasına katkıda bulunur, emzirme ile bebek ölümleri azalır. Bugün anneler anne sütü ve emzirme konusundaki yeterli bilgiye sahip olmadıkları, anne sütüyle beslenme konusunda yeterli teşvik ve desteği görmedikleri için, her gün üç dört bin, yılda bir milyonun üzerinde bir yaşından küçük bebek ölmektedir.
Oysa bu bebeklerin ölümleri bebekler için en uygun beslenme şekli olan anne sütü ile beslenme ile önlenebilir (8). Bu nedenle gebe veya yeni doğan annelerinin veya emziren annelerin anne sütü konusundaki bilgi düzeyleri ve davranışlarının araştırılarak tespit edilmesi oldukça önemlidir. Bu bağlamda ülkemizde pek çok bilimsel araştırma yapılmış olup $(9,10,11,12,13,14,15,16,17,18,19)$, bu araştırmalarda genel olarak gebe veya annelerin bilgi düzeylerinin yetersiz veya orta düzeyde olduğu tespit edilmiştir.

Bebek dostu ortamların sağlanarak emzirmenin ve anne sütü ile beslenmenin arttırılabilmesi için öncelikle sağlık kuruluşları, karar verme organları ve dolayısıyla toplumdaki bireylerin anneleri emzirme yönünde desteklemeleri önem taşımaktadır (20). Bu bağlamda Türkiye'de gebeliklerinden itibaren anne adaylarını anne sütü ve emzirme konusunda bilgilendiren, doğumdan sonra annelerin bebeklerini emzirmesini sağlayan, emzirmeyi sürdürmesinde destekleyen, güncel bilgilerle eğitilmiş sağlık personeli yardımıyla annelere bebeklerini nasıl emzirecekleri konusunda yardımcı olan kurumlar "Bebek Dostu Sağlık Kuruluşu" unvanını almaktadır (21). Annelerin anne sütü ve emzirme konusunda yeterince bilgilendirilmelerinde, özellikle bu unvanı almış hastanelerde uygulanan faaliyetlerin etkili olduğu düşünülmektedir.

Bu çalışmada Aydın II Merkezi'ndeki "Bebek Dostu Sağlık Kuruluşu" unvanını almış Kadın Doğum ve Çocuk Hastalıkları Hastanesi'nde doğum yapan annelerin anne sütü ve emzirme hakkındaki, uygulama ve görüş ile bunu etkileyen faktörleri belirlemek amaçlanmıştır. Bu çalışma ayrıca Aydın ilinde bebek dostu bir hastanede yapılan ilk araştırma olması açısından da oldukça önemlidir.

\section{Gereç ve Yöntem}

Bu araştırma Aydın İı Merkezi'ndeki sağlık kurumlarından biri olan 'Bebek Dostu Hastane' olan Kadın Doğum ve Çocuk Hastalıkları Hastanesi'nde tanımlayıcı kesitsel yöntem ile Mart-Nisan-Mayıs ayları 2016 yılı içinde doğum yapan 280 kişi ile yapılan anket çalışmaları ile yürütülmüştür. UNICEF ve WHO tarafından 1991 de ve 2010 yılından bu yana da Sağlık Bakanlığımız tarafından ülkemizde bebek sağlığının geliştirilerek bebeğin anne sütü ile beslenmesini sağlamak ve desteklemek amaçıyla yürütülen ‘Bebek Dostu Hastaneler' programı bulunmaktadır. Bu programda "10 adımda başarılı emzirme" ilkelerinin uygulanması ile bebek ölümlerinin azaltılması, sağlıklı bir gelişim ve büyüme için bebeğin anne sütü ile emzirilmesini özendirmek amaçlanmaktadır (22). 
Evreni oluşturulan toplam doğum sayısı 1035 'tir. Örneklem sayısı 0.25 , etki boyu 0.05 , hata payı ve 0.80 güç ile 280 kişi olarak belirlenmiştir. Anket çalışması, sosyo-demografik bilgiler (11 adet), obstetrik özellikler (7 adet) ve emzirme ile ilgili özellikleri (15 adet) olmak üzere toplam 33 adet soru içermektedir. Sorular literatüre dayalı olarak araştırmacılar tarafından geliştirilmiştir $(16,23,24,25)$.

Aydın Kadın Doğum ve Çocuk Hastanesi dışında bir hastanede doğum yapmış olmak, Türkçe olarak iletişim kurulamayan hastalar, mental retarde olan, bebeği yeni doğan ünitesinde yatan hastalar araştırmaya dâhil edilmemiştir.

\section{Araştırmanın etik yönü}

Araştırmada anket ve bilgi formlarını içeren yazılı dokümanlar kullanılmıştır. Araştırma sırasında kullanılan anket ve bilgi formları, her gönüllü için araştırmacının sorumluluğunda saklanmıştır. Çalışmaya sadece gönüllüler katılmış olup, gönüllüler çalışma hakkında bilgilendirilmiştir. Çalışma için, Adnan Menderes Üniversitesi, Girişimsel Olmayan Klinik Araştırmalar Etik Kurulu'ndan izin alınmıştır (2016/774).

\section{Bulgular}

Tablo 1'de araştırmaya katılan 280 yeni doğum yapmış kadınların sosyodemografik özellikleri verilmiştir. Bu bağlamda, çalışmaya katılanların 21-30 yaş arasında $(\% 59,7)$, ilkokul mezunu $(\% 48,9)$ ve ev hanımı oldukları $(\% 80,7)$, çoğunluğunun şehir merkezinde yaşayan çekirdek aile olduğu tespit edilmiştir.

Tablo 2'de, çalışmaya katılan 280 kadının büyük çoğunluğunun ilk veya ikinci gebeliği olduğu ve genellikle normal doğumu tercih ettikleri, bebeklerin doğum kilosunun 3000-3499 g aralığında olduğu ve gebeliğin isteyerek planlı olarak gerçekleştiği tespit edilmiştir.

Ankete katılan kadınların emzirme ile ilgili uygulama ve görüşlerini ölçmeye yönelik sorular ve alınan cevaplar Tablo 3'de verilmiştir. Annelerin ilk gebelikte altı aydan fazla bebeklerini anne sütü ile besledikleri, buna ek olarak araştırmaya dahil edilen bebeklerini ortalama 2 yaşına kadar beslemeyi düşündükleri $(\% 73,9)$, çoğunluğunun bebeklerini anne sütü ile 10-20 dk besledikleri tespit edilmiştir. Annelerin çoğunluğunun bu doğumda ve doğumdan sonra sağlık personelinden çeşitli konularda eğitim aldıkları (Örn: anne sütü ve emzirme, emzirmenin nasıl yapılacağı, emzirmenin bebek için yararları, emzirmenin anne için yararları, emzirirken karşılaşılan sorunların çözüm yolları, emzirme sırasında beslenme vb.) tespit edilmiştir. Annelerin $\% 69,6^{\prime}$ sı emzirme başarılarının iyi düzeyde olduğunu belirtmişlerdir.
Tablo 1. Ankete katılanların sosyo demografik özellikleri $(n=280)$.

\begin{tabular}{lccc} 
Demografik özellik & Değişkenler & Sayı & Yüzde \\
\hline Yaş & 20 yaş ve altı & 38 & 13.6 \\
& $21-25$ yaş arası & 85 & 30.4 \\
& $26-30$ yaş arası & 82 & 29.3 \\
& 31 yaş ve üstü & 75 & 26.8 \\
\hline Eğitim durumu & İlkokul & 137 & 48.9 \\
& Ortaokul & 66 & 23.6 \\
& Lise & 43 & 15.4 \\
& Lisans ve lisans üstü & 34 & 12.1 \\
\hline Çalışma durumu & Hayır & 226 & 80.7 \\
& Evet & 54 & 19.3 \\
\hline Sağlık güvencesi durumu & Hayır & 21 & 7.5 \\
& Evet & 259 & 92.5 \\
\hline Eş çalışma durumu & Hayır & 11 & 3.9 \\
& Evet & 269 & 96.1 \\
\hline Gelir gider durumu & Gelir giderden az & 66 & 23.6 \\
& Gelir gidere eşit & 190 & 67.8 \\
& Gelir giderden fazla & 24 & 8.6 \\
\hline Aile tipi & Çekirdek aile & 200 & 71.4 \\
& Geniş aile & 80 & 28.6 \\
\hline Yaşadığınız yer & Köy & 60 & 21.4 \\
& Kasaba & 22 & 7.9 \\
& ilıçe & 81 & 28.9 \\
& Şehir merkezi & 117 & 41.8 \\
& Toplam & 280 & 100.0
\end{tabular}

Tablo 2. Ankete katıllanların obstetrik özellikleri $(n=280)$.

\begin{tabular}{|c|c|c|c|}
\hline Demografik özellik & Değişkenler & Sayı & Yüzde \\
\hline \multirow[t]{5}{*}{ Toplam gebelik sayısı } & 1 & 90 & 32.1 \\
\hline & 2 & 76 & 27.2 \\
\hline & 3 & 70 & 25.0 \\
\hline & 4 & 18 & 6.4 \\
\hline & 5 & 26 & 9.3 \\
\hline \multirow[t]{5}{*}{ Yaşayan çocuk sayısı } & 1 & 95 & 33.9 \\
\hline & 2 & 87 & 31.1 \\
\hline & 3 & 63 & 22.5 \\
\hline & 4 & 17 & 6.1 \\
\hline & 5 & 18 & 6.4 \\
\hline \multirow[t]{2}{*}{ Doğum şekli } & Normal doğum & 172 & 61.4 \\
\hline & Sezaryen doğum & 108 & 38.6 \\
\hline \multirow[t]{4}{*}{ Bebeğin kilosu } & $2999 \mathrm{~g}$ ve altı & 60 & 21.4 \\
\hline & $3000-3499 \mathrm{~g}$ arası & 137 & 48.9 \\
\hline & $3500-3999 \mathrm{~g}$ arası & 65 & 23.3 \\
\hline & $4000 \mathrm{~g}$ ve üstü & 18 & 6.4 \\
\hline \multirow[t]{2}{*}{ Gebeliği planlama durumu } & Hayır & 35 & 12.5 \\
\hline & Evet & 245 & 87.5 \\
\hline \multirow[t]{3}{*}{ Bebeği isteme durumu } & Hayır & 10 & 3.6 \\
\hline & Evet & 270 & 96.4 \\
\hline & Toplam & 280 & 100.0 \\
\hline
\end{tabular}


Tablo 3. Ankete katılanların emzirme ile ilgili özellikleri $(n=280)$.

\begin{tabular}{|c|c|c|c|}
\hline Demografik özellik & Değişkenler & Sayı & Yüzde \\
\hline \multirow{3}{*}{$\begin{array}{l}\text { Önceki çocuğunu } \\
\text { besleme durumu }\end{array}$} & İlk gebelik & 89 & 31.8 \\
\hline & Anne sütü & 182 & 65.0 \\
\hline & Diğer & 9 & 3.2 \\
\hline \multirow{3}{*}{$\begin{array}{l}\text { Önceki çocuğu sadece } \\
\text { anne sütü ile besleme durumu }\end{array}$} & İlk gebelik & 89 & 31.8 \\
\hline & Altı aydan az & 35 & 12.5 \\
\hline & Altı ay ve üstü & 156 & 55.7 \\
\hline \multirow{3}{*}{$\begin{array}{l}\text { Şimdiki bebeği anne sütü ile } \\
\text { besleme süresi düşüncesi }\end{array}$} & 6 ay ve altı & 182 & 65.0 \\
\hline & 8-18 ay arası & 39 & 13.9 \\
\hline & 24 ay ve üstü & 59 & 21.1 \\
\hline \multirow{3}{*}{$\begin{array}{l}\text { Şimdiki bebeği emzirmeyi } \\
\text { düşünme yaşı }\end{array}$} & 12 ay ve altı & 37 & 13.2 \\
\hline & 13-24 ay arası & 207 & 73.9 \\
\hline & 24 ay üstü & 36 & 12.9 \\
\hline \multirow{3}{*}{$\begin{array}{l}\text { Bu doğumdan sonra bebeği } \\
\text { ilk besleme durumu }\end{array}$} & Anne sütü & 277 & 98.9 \\
\hline & Mama & 2 & 0.7 \\
\hline & Serum & 1 & 0.4 \\
\hline \multirow{3}{*}{$\begin{array}{l}\text { Bu bebeği doğumdan sonra } \\
\text { ilk emzirme süresi }\end{array}$} & İlk yarım saat içinde & 233 & 83.2 \\
\hline & İlk bir saat içinde & 25 & 8.9 \\
\hline & İlk 2 saat ve daha geç & 22 & 7.9 \\
\hline \multirow[t]{3}{*}{ Bu bebeği emzirme süresi } & $15 \mathrm{dk}$ ve altı & 123 & 43.9 \\
\hline & $16-20 \mathrm{dk}$ arası & 87 & 31.1 \\
\hline & $21 \mathrm{dk}$ üstü & 70 & 25.0 \\
\hline \multirow{2}{*}{$\begin{array}{l}\text { Bu gebelikte anne sütü ve } \\
\text { emzirme konusunda eğitim } \\
\text { alma durumu }\end{array}$} & Hayır & 57 & 20.4 \\
\hline & Evet & 223 & 79.6 \\
\hline \multirow{3}{*}{$\begin{array}{l}\text { Bu gebelikte anne sütü ve } \\
\text { emzirme konusunda eğitimi } \\
\text { kimden aldığı }\end{array}$} & Eğitim almadım & 41 & 14.6 \\
\hline & Sağlık personeli & 231 & 82.5 \\
\hline & Diğer & 8 & 2.9 \\
\hline \multirow{2}{*}{$\begin{array}{l}\text { Doğumdan sonra anne sütü } \\
\text { ve emzirme konusunda eğitim } \\
\text { alma durumu }\end{array}$} & Hayır & 38 & 13.6 \\
\hline & Evet & 242 & 86.4 \\
\hline \multirow[t]{3}{*}{ Emzirme desteği alınacak kişi } & Destek almayacak & 20 & 7.1 \\
\hline & Eşimden & 169 & 60.4 \\
\hline & Diğer (Anne-Kardeş gb) & 91 & 32.5 \\
\hline \multirow{4}{*}{$\begin{array}{l}\text { Emzirme başarısını } \\
\text { değerlendirme durumu }\end{array}$} & İyi & 195 & 69.6 \\
\hline & Orta & 81 & 29.0 \\
\hline & Kötü & 4 & 1.4 \\
\hline & Toplam & 280 & 100.0 \\
\hline
\end{tabular}

Yeni doğum yapmış annelerin bebeklerini anne sütü ile besleme süresi hakkındaki düşünceleri ile diğer değişken grupları arasındaki ilişkileri tespit etmek için Ki-Kare Testi uygulanmış olup, sonuçlar Tablo 4'de gösterilmiştir. Yapılan Ki-Kare testi sonucuna göre (Tablo 4), annelerin bebeklerini anne sütü ile besleme süresi düşünceleri üzerine annenin çalışma durumunun $(p>0,05)$ etkili olmadığı belirlenmiştir. Annelerin bebeklerini anne sütü ile besleme süresi düşünceleri üzerine annenin eğitim durumunun etkili olduğu belirlenmiştir $(p<0,05)$. Diğer taraftan annenin gebelikte ve doğumdan sonra çeşitli eğitimler almasının ve emzirme süresince eşten alınacak çeşitli desteklerin annenin bebeğini emzirme süresinde önemli düzeyde etkili olabileceği $(p<0,05)$ tespit edilmiştir.

\section{Tartışma}

Anne sütü ile emzirmenin hem bebek, hem de anne için, başta beslenme olmak üzere, sağlık, bağışıklık, gelişimsel, psikolojik, sosyal ve ekonomik yönden çok sayıda yararı olduğu bilinmektedir. Yaşamlarının ilk altı ayı içerisinde bebeklere verilebilecek en ideal besin anne sütüdür. WHO ve UNICEF'in dünya çapında yürüttükleri çocuk sağlığı ve herkes için sağlık programlarında anne sütü ile beslenme, temel sağlık önerileri içinde anahtar bir öğe olarak yer almaktadır (26). Anne sütü ile yeterli ve doğru beslenme, bebeklerin motor-mental ve psikososyal gelişimlerini olumlu yönde etkilemektedir. Bu bakımdan anne sütünün önemini bütün kadınlara etkin bir şekilde aktarmak gerekmektedir (27).

Araştırmamıza katılan annelerin çoğunluğu 20-30 yaş arasında $(\% 59,7)$ olup, şehir merkezinde yaşayan çekirdek aileden oluşmaktadır. Annelerin \%72,5'inin ilkokul veya ortaokul mezunu, \%80,7'sinin ev hanımı oldukları, $\% 61,4$ 'ünün normal gebeliği tercih ettikleri belirlenmiş olup, \% 87,5'inin gebeliği planlı olarak gerçekleştirdikleri ve \%96,4'ünün isteyerek çocuk sahibi olmaları oldukça sevindiricidir (Tablo 1, Tablo 2). Türkiye Nüfus ve Sağlık Araştırması (TNSA) 2013 verilerine göre kadınların doğurganlık hızlarının doğurganlık çağlarının sonuna kadar devam ettiği ve doğurganlık hızlarının 25-29 yaş grubunda en yüksek olduğu belirtilmiştir. Araştırmamıza katılan kadınların 20 yaş altındaki anne sayısı \%13,6 olup, Türkiye ortalamasının üstünde olduğu tespit edilmiştir. Her ne kadar çalışmada kadınların çoğunluğunun şehir merkezinde yaşadığı $(\% 41,8)$ ortaya konmuş olsa da, erken yaş evlilikleri oranının yüksek olduğu görülmektedir. Mardin Kadın Doğum ve Çocuk Hastalıkları Hastanesi Kadın Doğum Kliniğinde 15-49 yaş arası anneler arasında yapılan bir çalışmada da benzer sonuçlar elde edilmiştir (13).

TNSA 2013 verilerine göre annelerin \%56,9'unun ilkokul ve ortaokul mezunu olduğu ve sadece $\% 31,1$ 'inin lise ve üzeri eğitim aldıkları belirtilmiştir. Araştırmamıza katılan annelerin $\% 27,5^{\prime}$ inin lise ve üstü eğitim almış oldukları saptanmış olup, bu bulgular ülke geneliyle uyumlu olup genel olarak annelerin yarısının bilgi ve eğitim düzeyinin ilkokul düzeyinde olduğu söylenebilir (Tablo 1). Diğer taraftan 
Tablo 4. Yeni doğum yapmış annelerin bebeklerini anne sütü ile besleme süresi hakkındaki uygulama ve görüşleri arasındaki ilişkiler ( $n=280)$

\begin{tabular}{|c|c|c|c|c|c|c|c|}
\hline \multirow{2}{*}{ Özellikler } & & \multicolumn{3}{|c|}{ Bebeği anne sütü ile besleme süresi düşüncesi } & \multirow[b]{2}{*}{ Toplam } & \multirow[b]{2}{*}{ Value } & \multirow[b]{2}{*}{ p. } \\
\hline & & 6 ay ve altı & 8-18 ay arası & 24 ay ve üstü & & & \\
\hline \multirow[t]{4}{*}{ Eğitim durumu } & İlkokul & $\begin{array}{c}100 \\
35.7 \%\end{array}$ & $\begin{array}{c}17 \\
6.1 \% \\
\end{array}$ & $\begin{array}{c}20 \\
7.1 \% \\
\end{array}$ & $\begin{array}{c}137 \\
48.9 \% \\
\end{array}$ & \multirow{4}{*}{$13.651^{\mathrm{a}}$} & \multirow{4}{*}{.034} \\
\hline & Ortaokul & $\begin{array}{c}37 \\
13.2 \% \\
\end{array}$ & $\begin{array}{c}11 \\
3.9 \% \\
\end{array}$ & $\begin{array}{c}18 \\
6.4 \%\end{array}$ & $\begin{array}{c}66 \\
23.6 \% \\
\end{array}$ & & \\
\hline & Lise & $\begin{array}{c}27 \\
9.6 \%\end{array}$ & $\begin{array}{c}8 \\
2.9 \%\end{array}$ & $\begin{array}{c}8 \\
2.9 \%\end{array}$ & $\begin{array}{c}43 \\
15.4 \%\end{array}$ & & \\
\hline & Lisans ve lisans üstü & $\begin{array}{c}18 \\
6.4 \% \\
\end{array}$ & $\begin{array}{c}3 \\
1.1 \% \\
\end{array}$ & $\begin{array}{c}13 \\
4.6 \% \\
\end{array}$ & $\begin{array}{c}34 \\
12.1 \% \\
\end{array}$ & & \\
\hline Toplam & & $\begin{array}{c}182 \\
65.0 \% \\
\end{array}$ & $\begin{array}{c}39 \\
13.9 \% \\
\end{array}$ & $\begin{array}{c}59 \\
21.1 \% \\
\end{array}$ & $\begin{array}{c}280 \\
100.0 \% \\
\end{array}$ & & \\
\hline \multirow[t]{2}{*}{ Çalışma durumu } & Hayır & $\begin{array}{c}148 \\
52.9 \%\end{array}$ & $\begin{array}{c}32 \\
11.4 \%\end{array}$ & $\begin{array}{c}46 \\
16.4 \%\end{array}$ & $\begin{array}{c}226 \\
80.7 \%\end{array}$ & \multirow{2}{*}{$.374^{\mathrm{a}}$} & \multirow{2}{*}{.830} \\
\hline & Evet & $\begin{array}{c}34 \\
12.1 \%\end{array}$ & $\begin{array}{c}7 \\
2.5 \%\end{array}$ & $\begin{array}{c}13 \\
4.6 \%\end{array}$ & $\begin{array}{c}54 \\
19.3 \%\end{array}$ & & \\
\hline Toplam & & $\begin{array}{c}182 \\
65,0 \%\end{array}$ & $\begin{array}{c}39 \\
13.9 \%\end{array}$ & $\begin{array}{c}59 \\
21.1 \%\end{array}$ & $\begin{array}{c}280 \\
100.0 \%\end{array}$ & & \\
\hline \multirow[t]{3}{*}{ Gelir gider durumu } & Gelir giderden az & $\begin{array}{c}33 \\
11.8 \%\end{array}$ & $\begin{array}{c}11 \\
3.9 \%\end{array}$ & $\begin{array}{c}22 \\
7.9 \%\end{array}$ & $\begin{array}{c}66 \\
23.6 \%\end{array}$ & \multirow{3}{*}{$10.037^{\mathrm{a}}$} & \multirow{3}{*}{.040} \\
\hline & Gelir gidere eşit & $\begin{array}{c}131 \\
46.8 \%\end{array}$ & $\begin{array}{c}25 \\
8.9 \% \\
\end{array}$ & $\begin{array}{c}34 \\
12.1 \%\end{array}$ & $\begin{array}{c}190 \\
67.9 \%\end{array}$ & & \\
\hline & Gelir giderden fazla & $\begin{array}{c}18 \\
6.4 \%\end{array}$ & $\begin{array}{c}3 \\
1.1 \% \\
\end{array}$ & $\begin{array}{c}3 \\
1.1 \% \\
\end{array}$ & $\begin{array}{c}24 \\
8.6 \%\end{array}$ & & \\
\hline Toplam & & $\begin{array}{c}182 \\
65,0 \%\end{array}$ & $\begin{array}{c}39 \\
13.9 \%\end{array}$ & $\begin{array}{c}59 \\
21.1 \%\end{array}$ & $\begin{array}{c}280 \\
100.0 \%\end{array}$ & & \\
\hline \multirow{2}{*}{ Bebeği isteme durumu } & Hayır & $\begin{array}{c}4 \\
1.4 \%\end{array}$ & $\begin{array}{c}4 \\
1.4 \%\end{array}$ & $\begin{array}{c}2 \\
.7 \%\end{array}$ & $\begin{array}{c}10 \\
3.6 \%\end{array}$ & \multirow{2}{*}{$6.064^{\mathrm{a}}$} & \multirow{2}{*}{.048} \\
\hline & Evet & $\begin{array}{c}178 \\
63.6 \%\end{array}$ & $\begin{array}{c}35 \\
12.5 \%\end{array}$ & $\begin{array}{c}57 \\
20.4 \%\end{array}$ & $\begin{array}{c}270 \\
96.4 \%\end{array}$ & & \\
\hline Toplam & & $\begin{array}{c}182 \\
65.0 \%\end{array}$ & $\begin{array}{c}39 \\
13.9 \%\end{array}$ & $\begin{array}{c}59 \\
21.1 \%\end{array}$ & $\begin{array}{c}280 \\
100.0 \%\end{array}$ & & \\
\hline \multirow{2}{*}{$\begin{array}{l}\text { Bu gebelikte anne sütü ve } \\
\text { emzirme konusunda } \\
\text { eğitim alma durumu }\end{array}$} & Hayır & $\begin{array}{c}20 \\
7.1 \%\end{array}$ & $\begin{array}{c}15 \\
5.4 \%\end{array}$ & $\begin{array}{c}22 \\
7.9 \% \\
\end{array}$ & $\begin{array}{c}57 \\
20.4 \%\end{array}$ & \multirow{2}{*}{$28.168^{\mathrm{a}}$} & \multirow{2}{*}{.000} \\
\hline & Evet & $\begin{array}{c}162 \\
57.9 \%\end{array}$ & $\begin{array}{c}24 \\
8.6 \% \\
\end{array}$ & $\begin{array}{c}37 \\
13.2 \%\end{array}$ & $\begin{array}{c}223 \\
79.6 \%\end{array}$ & & \\
\hline Toplam & $\begin{array}{c}182 \\
65.0 \%\end{array}$ & $\begin{array}{c}39 \\
13.9 \%\end{array}$ & $\begin{array}{c}59 \\
21.1 \%\end{array}$ & $\begin{array}{c}280 \\
100.0 \%\end{array}$ & & & \\
\hline \multirow{2}{*}{$\begin{array}{l}\text { Doğumdan sonra anne sütü ve } \\
\text { emzirme konusunda eğitim alma } \\
\text { durumu }\end{array}$} & Hayır & $\begin{array}{c}14 \\
5.0 \%\end{array}$ & $\begin{array}{c}10 \\
3.6 \%\end{array}$ & $\begin{array}{c}14 \\
5.0 \%\end{array}$ & $\begin{array}{c}38 \\
13.6 \%\end{array}$ & \multirow{2}{*}{$15.396^{a}$} & \multirow{2}{*}{.000} \\
\hline & Evet & $\begin{array}{c}168 \\
60.0 \% \\
\end{array}$ & $\begin{array}{c}29 \\
10.4 \% \\
\end{array}$ & $\begin{array}{c}45 \\
16.1 \% \\
\end{array}$ & $\begin{array}{c}242 \\
86.4 \%\end{array}$ & & \\
\hline Toplam & & $\begin{array}{c}182 \\
65.0 \%\end{array}$ & $\begin{array}{c}39 \\
13.9 \% \\
\end{array}$ & $\begin{array}{c}59 \\
21.1 \% \\
\end{array}$ & $\begin{array}{c}280 \\
100.0 \% \\
\end{array}$ & & \\
\hline \multirow{2}{*}{$\begin{array}{l}\text { Emzirme sürecinde } \\
\text { eşten alınacak psikolojik destek }\end{array}$} & Hayır & $\begin{array}{c}114 \\
40.7 \%\end{array}$ & $\begin{array}{c}16 \\
5.7 \%\end{array}$ & $\begin{array}{c}23 \\
8.2 \%\end{array}$ & $\begin{array}{c}153 \\
54.6 \%\end{array}$ & \multirow{2}{*}{$13.449^{\mathrm{a}}$} & \multirow{2}{*}{.001} \\
\hline & Evet & $\begin{array}{c}68 \\
24.3 \% \\
\end{array}$ & $\begin{array}{c}23 \\
8.2 \% \\
\end{array}$ & $\begin{array}{c}36 \\
12.9 \% \\
\end{array}$ & $\begin{array}{c}127 \\
45.4 \% \\
\end{array}$ & & \\
\hline Toplam & & $\begin{array}{c}182 \\
65,0 \%\end{array}$ & $\begin{array}{c}39 \\
13.9 \% \\
\end{array}$ & $\begin{array}{c}59 \\
21.1 \% \\
\end{array}$ & $\begin{array}{c}280 \\
100.0 \%\end{array}$ & & \\
\hline \multirow{2}{*}{$\begin{array}{l}\text { Emzirme sürecinde } \\
\text { eşten alınacak ev işlerinde } \\
\text { destek }\end{array}$} & Hayır & $\begin{array}{c}154 \\
55.0 \%\end{array}$ & $\begin{array}{c}22 \\
7.9 \% \\
\end{array}$ & $\begin{array}{c}19 \\
6.8 \% \\
\end{array}$ & $\begin{array}{c}195 \\
69.6 \% \\
\end{array}$ & \multirow{2}{*}{$61.646^{a}$} & \multirow{2}{*}{.000} \\
\hline & Evet & $\begin{array}{c}28 \\
10.0 \% \\
\end{array}$ & $\begin{array}{c}17 \\
6.1 \% \\
\end{array}$ & $\begin{array}{c}40 \\
14.3 \% \\
\end{array}$ & $\begin{array}{c}85 \\
30.4 \% \\
\end{array}$ & & \\
\hline Toplam & & $\begin{array}{c}182 \\
65.0 \%\end{array}$ & $\begin{array}{c}39 \\
13.9 \%\end{array}$ & $\begin{array}{c}59 \\
21.1 \%\end{array}$ & $\begin{array}{c}280 \\
100.0 \%\end{array}$ & & \\
\hline Emzirme sürecinde eşten & Hayır & $\begin{array}{c}132 \\
47.1 \%\end{array}$ & $\begin{array}{c}24 \\
8.6 \%\end{array}$ & $\begin{array}{c}20 \\
7.1 \%\end{array}$ & $\begin{array}{c}176 \\
62.9 \%\end{array}$ & $28512 a$ & חกח \\
\hline destek & Evet & $\begin{array}{c}50 \\
17.9 \%\end{array}$ & $\begin{array}{c}15 \\
5.4 \%\end{array}$ & $\begin{array}{c}39 \\
13.9 \%\end{array}$ & $\begin{array}{c}104 \\
37.1 \%\end{array}$ & $28.512^{a}$ & .000 \\
\hline Toplam & & $\begin{array}{c}182 \\
65.0 \%\end{array}$ & $\begin{array}{c}39 \\
13.9 \%\end{array}$ & $\begin{array}{c}59 \\
21.1 \%\end{array}$ & $\begin{array}{c}280 \\
100.0 \%\end{array}$ & & \\
\hline
\end{tabular}


ülkemizde sezaryen ile doğum çok yaygın olup, TNSA-2013 verilerine göre 2008-2013 yılları arasında ülkemizdeki tüm doğumların \%48'si sezaryen ile yapılmış olsa bile, araştırmamıza katılan annelerin çoğunun eğitim düzeylerinin ilkokul düzeyinde olmasına rağmen, büyük bir çoğunluğunun sezaryen doğumu tercih etmemeleri $(\% 61,4)$ dikkat çekicidir (Tablo 2). Bu durum Mersin Devlet Hastanesi ve Toros Devlet Hastanesindeki annelerin eğitim düzeyleri düşük olmasına rağmen yüksek oranda $(\% 73,9)$ sezaryen ile doğum yapmaları ile de çelişmektedir (18).

Anketimize katılan annelerin çoğunluğu ev hanımı $(\% 80,7)$ olup, eşleri çalışmakta $(\% 96,1)$ ve eşleri dolayısıyla sağlık güvenceleri $(\% 92,5)$ bulunmaktadır (Tablo 1). Kahramanmaraş il merkezindeki çeşitli sağlık ocağı bölgelerinde 0-6 ay çocuğu olan anneler üzerine yapılan bir araştırmada, bulgularımıza paralel olarak, annelerin büyük çoğunluğunun ev hanımı $(\% 80,2)$ olmalarına rağmen $\% 90,7$ 'sinin sağlık güvencesinin olduğu tespit edilmiştir (15).

Anketimize katılan annelerin emzirme ile ilgili uygulama ve görüşlerini ölçmeye yönelik sorulara alınan cevaplar Tablo 3'de verilmiştir. TNSA 2013 verilerine göre tüm çocuklar için ortanca emzirme süresi 17 ay olup, emzirme $\% 96$ 'lık bir oranda ülkemizde oldukça yaygındır. Bu bulgu, araştırmamıza katılan annelerin önceki çocuklarını anne sütü ile 6 aydan fazla beslemeleri, yeni doğan bebeklerini de $13-24$ ay beslemeyi düşünmeleriyle $(\% 73,9)$ örtüşmektedir. Yeni Zelanda'da doğum sonrasında annelerin emzirme oranı \%88 iken, bu oran üç ayın sonunda \%42'ye ve 12 ay sonunda ise \%34'e düştüğü tespit edilmiştir (28).

Çalışmamıza dâhil olan annelerin $\% 98,9^{\prime}$ u bebeklerini doğumdan hemen sonra anne sütü ile emzirdikleri belirlenmiş, ilk yarım saat içinde emziren annelerin oranının $\% 83,2$ olduğu ve ilk bir saat içinde emziren annelerin ise $\% 8,9$ olduğu ortaya konmuş ve ortalama emzirme süresinin 15-20 dakika (\%75) olduğu tespit edilmiştir (Tablo 3). TNSA 2013 yılı raporuna göre çocukların \%50'sinin doğumdan sonraki ilk bir saat içinde emzirilmeye başladığı belirtilmiştir. TBSA 2014 yılı verilerine göre ise bu oranın \%59,1 olduğu, \%30,4'ünün ise 1-11 saat içinde emzirilmiş olduğu raporlanmıştır. İstanbul, Kahramanmaraş ve Mersin'de yapılan benzer çalışmalarda bu oran sırasıyla \%47,4, \%69,3 ve $\% 69,9$ olarak bulunmuştur $(15,18,23)$. Bu çalışmaların sonuçlarının, araştırmamıza katılan ve ilk yarım ve bir saat içinde emzirmeye başlama oranlarından düşük olduğu saptanmıştır. Bunun nedenin ise araştırmayı yaptığımız hastanenin bebek dostu hastane olması ve annelerin emzirme konusunda desteklenmesinden kaynaklandığı düşünülmektedir.
Annelerin büyük çoğunluğu $(\% 92,5)$ eşleri dolayısıyla sağlık güvenceleri bulunduğu için (Tablo 1) hastanelerin çocuk polikliniklerine veya sağlık ocağına giderek hekim veya ebeler gibi sağlık personellerinden anne sütü ve emzirme konusunda eğitim aldıklarını $(\% 82,5)$ belirtmişlerdir (Tablo 3). Ülkemizde doğum öncesinde emzirme ve anne sütü ile ilgili bilgi düzeyi üzerine yapılan çalışmalara bakıldığında bu oranın daha düşük $(\% 32,7, \% 37,1, \% 76,7)$ olduğu görülmektedir $(16,23,29)$. Oysaki araştırmamıza katılan anneler doğumdan sonra emzirme konularında çeşitli eğitimler (anne sütü ve emzirme, emzirmenin nasıl yapılacağı, emzirmenin bebek için yararları, emzirmenin anne için yararları, emzirirken karşılaşılan sorunlar, emzirme sırasında beslenme vb.) aldıklarını belirtmişlerdir. Doğumdan sonra anne sütü ve emzirme konusunda eğitim alma durumu oldukça yüksek olup, $\% 86,4$ 'dür (Tablo 3). Bebek dostu unvanı bulunan hastanelerde doğum yapan annelerin genel olarak emzirme konusunda bilgi alma durumlarının yüksek olması gerektiği belirtilmektedir (18). Adıyaman merkez, ilçe ve köylerinde yapılan benzer bir çalışmada annelerin anne sütü ile ilgili bilgi alma durumlarının \%21,1-58,9 olduğu ve en az bilgilendirmenin köylerde yapıldığı saptanmıştır (24). Tanzanya'da son yıllarda yapılan bir çalışmada ise bu oranın düşük (\%49) olduğu saptanmıştır (9). Mersin'de 'Bebek Dostu' hastanelerde yapılan bir çalışmada ise bu oran $\% 68,5^{\prime}$ dir (18). Bulgularımızın, gerek ülkemizde gerekse yurt dışında bu konuda yapılan çalışmalarda elde edilen verilerden yüksek bulunması son yıllarda ülkemizdeki 'Bebek Dostu' hastanelerin bu alanda etkin hizmet verdiklerini ve annelerde bilinç artışııın sağlandığı görüşünü kuvvetlendirmektedir. Araştırmanın yapıldığı hastane 2016 yılından itibaren Bebek Dostu bir hastanedir (22).

Babalar, doğum sonrası annelerin emzirmesinin devamlılığında önemli rolleri bulunmakta olduğu ve bu nedenle anne sütü ve emzirmenin önemi ve gerekliliği hakkında bilgilendirilmesi gerektiği belirtilmektedir (23). Çalışmamızda annelerin büyük bir çoğunluğu her ne kadar emzirme konularında kendilerini iyi olarak $(\% 69,6)$ değerlendirmiş olsalar da, eşlerinden destek alacak olduklarını $(\% 60,4)$ belirtmişlerdir (Tablo 3). Bu noktada çeşitli yasal düzenlemeler ile annelerin emzirme sürelerini arttırmak için babalara yönelik uygulamaların desteklenmesi gerekmektedir.

Emzirme başarısı “Emzirme süresi emzirme başarısını göstermektedir", "Başarılı emzirme, annenin kendini başarılı hissetmesidir", "Başarılı emzirme, anne ve bebeğin ihtiyaçlarının karşılıklı tatmin olmasıyla sonuçlanan interaktif bir süreç" olarak literatürde farklı tanımlanmakta olup, 
annelerin emzirmeye ilişkin desteklenmesinin ve cesaretlendirilmesinin emzirmeyi olumlu yönde etkileyerek annelerin emzirme sürelerinin daha uzun olmasını sağladığı belirtilmektedir $(25,30,31)$. Bu bulgular, araştırmamızda da kendi emzirmesini başarılı bulan annelerin oranı ile $(\% 69,6)$, yeni doğan bebeklerini uzun süre (13-24 ay) beslemeyi düşünenlerin oranının $(\% 73,9)$ benzer ve yüksek olması ile örtüşmektedir (Tablo 3).

UNICEF ve Dünya Sağlık Örgütü (DSÖ) tavsiyelerine göre çocukların yaşamlarının ilk 6 ayında sadece anne sütü ile beslenmesi, gerekiyorsa 6 . aydan sonra ek gıda ve lapaya başlanarak emzirmeye iki yaşına kadar devam edilmesi önerilmektedir. TNSA-2013 sonuçları ise ne yazık ki ülkemizde bebeklerin yüzde 58'inin yaşamın ilk iki ayında sadece anne sütü ile beslendiğini, çocuğun yaşıyla birlikte hızla azalarak 4-5 aylık bebeklerde bu oranın yüzde 10'a kadar gerilediğini göstermektedir. Emzirme süresi için, anne sütü konusunda bilgi sahibi annelerin daha uzun süre bebeklerine anne sütü verdiği; annenin emzirme kararlııı̆ında; babanın bu konudaki desteğinin ve annenin bu konuda kendine olan güveninin de etkili olabileceğini belirtilmiştir (17). Annenin eğitim düzeyinin yüksek olması bebeği daha uzun süre emzirmeye devam etmesi ile ilişkili olup, emzirme süresinin arttığını gösteren çalışmalar bulunmaktadır $(32,33)$. Bu çalışmada annelerin bebeklerini anne sütü ile besleme süresi düşünceleri üzerine; annenin eğitim durumunun, gelir-gider durumunun ve bebeği isteyip istemediğinin etkili olduğu ortaya konmuş $(p<0,05)$ olup, annenin çalışma durumunun etkili olmadığı belirlenmiştir ( $p>0.05$ ). Ayrıca çalışmamızda annenin gebelikte ve doğumdan sonra çeşitli eğitimler (anne sütü ve emzirme, doğumdan sonra emzirmenin bebek ve anne için yararları, emzirme döneminde beslenme eğitimleri) almasının

\section{Kaynaklar}

1. Gür E. Anne sütü ile beslenme. Türk Pediatri Arşivi 2007; 42: 11-5. https://www.journalagent.com/tpa/pdfs/TPA_42_SUP_1_11_15.pdf

2. WHO: infant and young child feeding: a tool for assessing national practices, policies and programmes; Geneva 2003. Web:http://www. who.int/nutrition/publications/inf_assess_nnpp_eng.pdf

3. Neyzi O. Pediatri (3. Baskı). Nobel Tıp Kitabevleri, İstanbul, 2002.ISBN: 9789754207194

4. Piper KM, Berry CA, Cregan MD. Thebioactivenature of human breast milk. Breastfeed Rev 2007;15: 5-10.

5. Bağ Ö. Annelerin anne sütü hakkındaki bilgi düzeyi ve emzirmeyi etkileyen psikososyal faktörler. Uzmanlık Tezi, Tepecik Eğitim ve Araştırma Hastanesi Çocuk Sağlığı ve Hastalıkları Klinikleri, 2006.

6. Topal S, Çınar N, Altınkaynak S. Süt çocukluğu döneminde beslenme. Düzce Üniversitesi Sağlık Bilimleri Enstitü Dergisi 2016; 6: 63-70.

7. Uyar E. Yeni doğum yapmış annelerin emzirme durumları. Marmara Üniversitesi Sağlık Eğitim Fakültesi Mezuniyet Tezi, 2000. ve emzirme süresince eşten alınacak çeşitli desteklerin, annelerin bebeklerini anne sütü ile besleme süresi düşünceleri üzerine önemli düzeyde etkili olabileceği $(p<0.05)$ saptanmıştır (Tablo 4). Elde edilen sonuçlar, araştırmamıza katılan annelerin bebeklerini emzirme süresinin artmasında, doğum öncesi ve doğum sonrası eğitimler ile uygulamalarının ve görüşlerinin geliştirildiğinin sağlandığı düşünülmektedir. Başarılı bir emzirmenin başlatılması ve sürdürülmesinde verilen eğitimin rolü büyüktür.

\section{Sonuç ve Öneriler}

Aydın ilindeki ilk 'Bebek dostu' olan hastanede yapılan bu çalışmada araştırmamıza katılan yeni doğum yapmış annelerin çoğunluğunun ilkokul ve ya ortaokul mezunu, ev hanımı, şehir merkezinde yaşayan, sağlık güvencesi olan ve genellikle normal doğumu tercih eden annelerden oluşmakta olduğu belirlenmiştir. Annelerin çoğunluğu Türkiye ortalamasının üstünde bir oranda bebeklerini doğumdan hemen sonra anne sütü ile $(\% 98,9)$ ilk yarım saat içinde veya bir saat içinde emzirdikleri belirlenmiştir. Annelerin çoğunluğunun gebelikte ve doğumdan sonra sağlık personelinden anne sütü ve emzirme konusunda çeşitli eğitimler aldığı tespit edilmiştir. Ki-Kare testi sonuçlarına göre annenin bebeğini emzirme süresinde annenin eğitim durumunun, annenin gebelikte ve doğumdan sonra çeşitli eğitimler almasının ve emzirme süresince eşten alınacak çeşitli desteklerin en önemli etkenler olduğu saptanmıştır. Bu sonuçlar doğrultusunda bebek dostu hastaneler başta olmak üzere tüm sağlık kurumlarında çeşitli yasal düzenlemeler ile annelerin emzirme sürelerini arttırmak için babalara yönelik uygulamaların desteklenmesi gerekmektedir. Ayrıca annelere verilen eğitimlerin yinelenmesinin, ev ziyaretleri yoluyla izlenmesinin ve davranışa dönüşüm sürecinde etkili olacağı ön görülmektedir.

8. Valman HB. Yaşamın ilk yılı ABC Dizisi, (1) Pfizer Illaçları A.Ş.,1999.

9. Hashim TH, Mgongo M, Katanga J, Uriyo GJ, Damian DJ, StrayPedersen B, et al. Predictors of appropriate breastfeeding knowledge among pregnant women in Moshi Urban, Tanzania: a cross-sectional Study. International Breastfeeding Journal 2017; 12: 2-8. [CrossRef]

10. Pektaş MK, Mutlu MF. Gebe kadınların emzirme ve anne sütü konusundaki bilgilerinin, tutum ve davranışlarının değerlendirilmesi. Gazi Medikal Journal 2016;27:145-8. [CrossRef]

11. Boff ADG, Paniagua LM, Scherer S, Garcia de Goulart BN. Mother's social/ economic aspects and level of knowledge about breastfeeding. Audiol Commun Res. 2015; 20: 141-5. [CrossRef]

12. Alfaleh KM. Perception and knowledge of breast feding among females in Saudi Arabia. Journal of Taibah University Medical Science 2014; 9: 139-42. [CrossRef]

13. İnanç BB. 15-49 yaş arası annelerin anne sütü ile ilgili uygulamaları ve etki eden faktörler. Türk Aile Hekimliği Dergisi 2013; 17: 51-5. [CrossRef] 
14. Dik K, Koyuncuoğlu E, Çelik HT, Korkmaz A. Annelerin bebek bakımı ve beslenmesi ile ilgili bilgi düzeyleri. Çocuk sağlığı ve hastalıkları dergisi 2012; 55: 77-81.

15. Özer A, Taş F, Ekerbiçer HÇ. 0-6 Aylık bebeği olan annelerin anne sütü ve emzirme konusundaki bilgi ve davranışları. TAF Preventive Medicine Bulletin 2010; 9: 315-20.

16. Uslu S, Can E, Özdemir H, Bülbül A. Bir yenidoğan ünitesinde annelerin anne sütü ile beslenme bilgi düzeyleri. Çocuk Dergisi 2010; 10: 82-5. [CrossRef]

17. Bağ Ö, Yaprak I, Halıcıoğlu O, Parlak Ö, Harputluoğlu N, Astarcıoğlu G. Annelerin anne sütü hakkındaki bilgi düzeyi ve sadece anne sütü ile beslenmeyi etkileyen psikososyal faktörler. İzmir Tepecik Eğitim Hastanesi Dergisi 2006; 16: 63-70. [CrossRef]

18. Eker A, Yurdakul M. Annelerin bebek beslenmesi ve emzirmeye ilişkin bilgi ve uygulamaları. Sted 2006; 15: 158-63.

19. Evren $E, A k d a g ̆ ~ R$, Şehriyaroğlu A. Yeni doğum yapan annelerin bebek bakımı ve beslenmesi ile ilgili bilgi düzeyleri. Atatürk üniversitesi Tıp Bülteni 1993; 25: 775-83.

20. Jones F, Green M. Baby friendly care. Can Nurse 1993; 89: 36-9

21. Tügdür M. Yüksek lisans tezi, Adnan Menderes Üniversitesi, Sağlık Bilimleri Enstitüsü, 2016.

22. TUSEB Türkiye Anne, Çocuk ve Ergen Sağlığı Enstitüsü. ulusal anne ve bebek dostu hastane kriterleri ve unvan alan hastaneler listesi, Aralık 2018. https://www.tuseb.gov.tr/enstitu/tacese/yuklemeler/ tacese_yayinlari/TACESE_2018_anne_bebek_dostu_hastane_ kriterleri liste.pdf

23. Ünsür EK, Demir Gündoğan B, Ünsür MT, Okan FF. Emziren annelerin emzirme ile ilgili bilgi ve tutumlarının değerlendirilmesi. Euras j Fam Med. 2014; 3:33-40.
24. Sabbağ Ç. Kent ve kırsalda annelerin 0-24 aylık çocukları besleme davranışları. IJHSS 2013; 10: 279-92.

25. Yenal K, Tokat M A, Ozan YD, Çeçe Ö, Abalın FB. Annelerin emzirme öz-yeterlilik algıları ile emzirme başarıları arasındaki ilişkinin incelenmesi. HEAD Hemşirelikte Eğitim ve Araştırma Dergisi 2013;10:14-9

26. Samur G. Anne sütü. Sağlık Bakanlığı Yayın No:726, 1. Baskı, Ankara: Klasmat Matbaacılık 2008.

27. Bülbül S, Kılınçkaya MF. 0 - 2 Yaş Grubu Bebeklerin Anne Sütü ile Beslenme Durumları ve Etkileyen Faktörler. KÜ Tıp Fak Derg 2013;15:15-20.

28. Health $A L$, Tuttle $C R$, Simons $M S$, Cleghorn $C L$, Parnell WR. $A$ longitudinal study of breastfeeding and weaning practices and weaning practices during the first year of life in Dunedin, New Zealand. J Am Diet Assoc 2002; 102: 937-43. [CrossRef]

29. Şahan H. 0-24 aylık bebeği olan annelerin anne sütü ve emzirme konusunda bilgi, tutum ve davranışları (tez). Kayseri, Erciyes Üniversitesi Tıp Fakültesi, 2008.

30. Sikorski J, Renfrew MJ, Pindoria P, Wade A. Support for breastfeeding mothers. Cochrane Database of Systematic Reviews 2002, Issue 1. Art. No.: CD001141. [CrossRef]

31. Odent M. Birth and Breastfeeding: Rediscovering the needs of women during pregnancy and childbirth. East Sussex, UK: Clairview Books; 2003.

32. Bertini G, Perugi S, Dani C, Pezzati M, Tronchin M, Rubaltelli FF. Maternal education and the incidence and duration of breast feeding: a prospective study. J Pediatr Gastroenterol Nutr 2003;37:447-52. [CrossRef]

33. Yılmaz G, Gurakan B, Akgun S, Ozbek N. Factors influencing breastfeeding for working mothers. Turk J Pediatr 2002;44: 30-4. 